\title{
МАЯТНИК ХХІ ВЕКА: ОРГАНИЗАЦИЯ КРУПНЕЙШЕГО МЕТАЛЛУРГИЧЕСКОГО ПРОИЗВОДСТВА НА БАЗЕ РУД ЧИНЕЙСКОГО И МАЛОТАГУЛЬСКОГО МЕСТОРОЖДЕНИЙ
}

\author{
А. Ф. Никольский', А. Ф. Шуплецов ${ }^{2}$ \\ ${ }^{1}$ Институт географии им. В. Б. Сочавы СО РАН, г. Иркутск, Российская Федерация \\ 2 Байкальский государственный университет, г. Иркутск, Российская Федерация
}

\section{Информация о статье}

Дата поступления

10 января 2018 г.

Дата принятия к печати 28 февраля 2018 г.

Дата онлайн-размещения 30 марта 2018 г.

\section{Ключевые слова}

Урало-Кузбасс; маятник; Ангара; «Новый Ангарстрой»; база индустриализации; металлургический цикл; черная металлургия; титаномагниевая промышленность; Байкальский регион

\section{Финансирование}

Работа выполнена

при финансовой поддержке РффИ и РГО в рамках проекта 17-05-41057 РГО_а «Транспортнокоммуникационный фрактор развития Сибири: возможности, ограничения, перспективы»

\begin{abstract}
Аннотация
Изложена концепция проекта «Новый Ангарстрой». В качестве его ключевой части рассматривается создание металлургического цикла производств общероссийского масштаба, включающего высококачественную черную металлургию и титаномагниевую промышленность, на основе ванадийсодержащих титаномагнетитовых руд зоны БАМа и Иркутской области, а также газа (Ковыктинское месторождение), угля (Иркутский бассейн) и гидроэнергии ангарских ГЭС. Возвратное движение составов от станции Новая Чара до Иркутска, Улан-Удэ, Читы, груженных сначала рудой, затем - металлопродукцией, а в обратном направлении - средствами производства, обеспечит функционирование этого маятника, подобного маятнику Урало-Кузбасса 1930-1940-х гг. Стратегические месторождения такого уровня, как Малотагульское и Чинейское, не должны разрабатываться в рамках проектов частных компаний. Их следует передать на разработку мощной общероссийской компании с полным государственным участием, каковой, например, являются «Российские железные дороги». Проект «Новый Ангарстрой» может быть реализован в оборонных, экспортных целях, в контексте несырьевого сотрудничества с КНР и другими странами и в рамках масштабных программ реконструкции Транссибирской и Байкало-Амурской магистралей и всей железнодорожной системы страны. Он призван развеять мифр о том, что основой будущего экономического процветания в регионе должны быть дальнейшая нещадная эксплуатация его лесных ресурсов, развитие экологически вредных химических производств и туристических отелей на Байкале.
\end{abstract}

\section{THE 21 ${ }^{\text {TH }}$ CENTURY BALANCE WHEEL: ORGANIZATION OF THE LARGEST METALLURGICAL PRODUCTION BASED ON ORES OF THE CHINEY AND MALOTAGUL DEPOSITS}

\author{
Alexey F. Nikolsky' ${ }^{1}$, Alexander F. Shupletsov ${ }^{2}$ \\ ${ }^{1}$ V. B. Sochava Institute of Geography SB RAS, Irkutsk, the Russian Federation \\ ${ }^{2}$ Baikal State University, Irkutsk, the Russian Federation
}

Article info

Received

January 10, 2018

Accepted

February 28, 2018

Available online

March 30, 2018

(๑ А. Ф. Никольский, А. Ф. Шуплецов, 2018

\section{Abstract}

The concept of the «New Angarstroy» project is presented. Its key part is the creation of the Russia-wide metallurgical production cycle, including high-quality ferrous metallurgy and titanium-magnesium industry on the basis of vanadium-containing titanomagnetite ores of the BAM zone and Irkutsk region, as well as on the basis of gas (the Kovykta field), coal (the Irkutsk basin) and hydropower (Angara hydropower stations). Trains loaded with ore at first and later with metal products will go from the Novaya Chara station to Irkutsk, Ulan-Ude, 


\section{Keywords}

Ural-Kuzbass; pendulum; the Angara; «New Angarstroy»; industrialization base; production cycle; ferrous metallurgy; titanium-magnesium industry; Baikal region

\section{Acknowledgements}

The study was carried out with the financial support of the Russian Foundation for Basic Research and the RGS project 17-05-41057 RGO_a «Transport

and Communication Factor of Siberia Development:

Opportunities, Constraints, Prospects»

Урало-Кузбасс (постановка проблемы). Период постсоветской стагнации в России так или иначе будет когда-то преодолен, и стране вновь потребуются масштабные научно проработанные проекты индустриального развития, подобные рассматриваемому в работе проекту «Новый Ангарстрой» - создания третьей (восточной) базы индустриализации России с опорой на Иркутскую область. Одной из особенностей этого проекта является предполагаемый возвратный (маятниковый) принцип движения железнодорожных составов, подобный тому, что был использован в проекте Урало-Кузнецкого комбината, запустивший в 1929 г. маятник прошлого, XX века. Работы по данному проекту начались ровно сто лет назад в 1918 г. по указанию В. И. Ленина, когда после подписания Брестского мира Россия оказалась отрезанной от южной металлургической базы. Но судьбоносное значение этого проекта тогда понимали не все. Руководитель секции Сибири и Дальнего Востока Госплана СССР с 1921 г. Н. Н. Колосовский писал в 1949 г.: «Минуло уже почти 20 лет с того момента, когда... создание Урало-Кузнецкого комбината было поставлено как первоочередная общегосударственная задача, а не как местное уральское или сибирское дело. <...> Можно было вместо того, чтобы идти в Сибирь, интенсифицировать использование европейских источников сырья и энергии... Однако этот путь требовал бы больше капитальных затрат... и больше расходов на живой труд... Все это задерживало бы развитие хозяйства, тогда как надо было ускорять темпы развития... выигрывая время. $\mathrm{K}$ этому надо добавить, что, во-первых, все европейские индустриальные центры СССР были уязвимы для нападений; во-вторых, они все же были недостаточны по мощности и разнообразию ресурсов. Известно, что наша первая угольно-металлургическая база была занята немцами в первые годы революции и разрушена ими во второй мировой войне. Исторический факт - во второй мировой войне СССР победил, опираясь на восточные оборонные базы Урала и Сибири... Исключительно большое значение Урало-Кузнецкого комбината ныне ясно каждому» [1, с. 9-14]1.

В основу Урало-Кузнецкого проекта Госплан СССР положил проект 1918 г. Общества сибирских инженеров в Томске (внеся затем в него ряд изменений): «Четыре завода коксового металла по 820 тыс. т каждый, три на Урале - Магнитогорский, Алапаевский, Бакальский и один в Кузбассе» [там же, с. 14-15]. Особенность состояла в том, что на Урале имелась железная руда, но отсутствовала необходимая угольная база, а в Кузнецком бассейне имелись в избытке коксующиеся угли, но не было своей руды. Идея проекта заключалась в том,

${ }^{1}$ Колосовский Николай Николаевич (1891-1954) советский экономист и экономико-географ, один из основателей отечественной районной школы экономической географии. Лауреат государственной премии первой степени (1942). В 1916 г. окончил Санкт-Петербургский институт инженеров путей сообщения и был отправлен в Забайкальский округ для строительства стратегических железных дорог. С 1921 г. по 1950-е гг. работал в Госплане СССР, Совете по изучению производительных сил (СОПС), структурах АН СССР, где занимался разработкой крупнейших проектов индустриального развития страны: Урало-Кузнецкий комбинат, Транссибирская сверхмагистраль, «Ангарстрой», освоение Севера. Во время войны руководил развертыванием военной промышленности на Урале и решением связанных с этим транспортных проблем. 
чтобы соединить уральские руды и кузнецкие коксующиеся угли для создания крупной черной металлургии как на Урале, так и в Западной Сибири, с перевозкой сырья и топлива железной дорогой на небывалое в мировой практике расстояние - 2200 км [2, с. 89-91].

В процессе исследований Госплана в 1921-1929 гг. были разбиты многочисленные возражения: 1) дороговизна перевозки сибирских углей на небывало далекие расстояния; 2) невозможность ее осуществления на одной двухпутной дороге; 3) якобы убыточность в проекте угля из-за нарушения веберовской теории размещения промышленности, согласно которой нерационально перевозить уголь, сгорающий в процессе производства, к руде; 4) отсутствие местных железных руд в районе строительства Кузнецкого завода. Первые два вопроса были сняты на основании теории электрических сверхмагистралей профессора Е. В. Михальцева. Третий вопрос был решен посредством конкретных расчетов. Четвертый вопрос - о недостатке руды в Кузбассе - был снят принятием в 1929 г. предложения Н. Н. Колосовского о загрузке угольного порожняка, следующего с Урала, магнитогорской рудой для Кузнецкого комбината. Это и создало (запустило) знаменитый маятник.

«За 15 лет советская социалистическая система индустриализации Урала и Сибири, - писал Н.Н. Колосовский [а другими словами - масштабный народно-хозяйственный подход к планированию], - позволила почти в 2 раза обогнать уровень производительности труда и энерговооруженности Западной Европы, где капитализм господствует 200 лет» [там же, с. 91].

Как видим, представление о низкой производительности труда в СССР в сравнении со странами Запада - миф. Другой миф что производительность общественного труда определяется выжиманием из него последних соков и оставлением за бортом жизни миллионов безработных. Производительность труда, как доказал опыт СССР, определяется его энерговооруженностью, низкой ценой этой энергии (и сырья) и огромными масштабами организуемого на их основе производства. Низкая производительность труда в России сегодня следствие высокой цены приватизированных источников энергии и сырья, сжатия масштабов производства, высокой безработицы и отсутствия народно-хозяйственного подхода к планированию. Возобновить тре- буемые масштабы производства и энерговооруженности труда в стране, резко снизить цену энергии и средств производства, ликвидировать безработицу и обеспечить высший в мире уровень производительности труда позволит запуск маятника XXI в.

Об этом «движителе» нашего времени, задуманном и начатом еще в прошлом веке, Н. Н. Колосовский писал: «Вполне возможно в течение, скажем, трех пятилеток построить в пределах территории Красноярск - Енисейск - Усть-Кут (на р. Лене) - Иркутск - Улан-Удэ могучее промышленное хозяйство нового типа с использованием энергии Ангары в масштабах, равных тем, которые достигаются современным использованием углей на Урале и в Кузнецком районе при эфффективности труда в 2-3 раза более высокой... Этот новый Восточно-Сибирский комбинат... позволит вовлечь в эксплуатацию громадные резервы... рудного, топливного, минерально-химического сырья Восточно-Сибирской платформы, Восточного Саяна, Бурятии, Восточного Забайкалья... приблизив центры индустрии к Дальнему Востоку, Якутии...» [1, с. 19-23].

Речь идет о проекте «Ангарстрой», начатом в 60-80-х гг. прошлого века в Восточной Сибири с выбором Иркутской области в качестве опорного региона.

"Ангарстрой". За 25-30 лет в Иркутской области были сорормированы крупнейшие, встроенные в единую систему страны топливно-энергетический, алюминиево-кремниевый, химический, лесной, машиностроительный, строительный, горнодобывающий комплексы. Менее чем 2 \% населения (именно столько проживает в Иркутской области) стали производить $7 \%$ российской электроэнергии (из них $90 \%-$ на одних из самых эфрфективных в стране и мире ГЭС), $21 \%$ каустической соды, $40 \%$ алюминия, 20 \% целлюлозы, 51 \% поливинилхлоридной смолы, 12 \% деловой древесины, 11 \% пиломатериалов, 6 \% картона, 13 \% фанеры. Интенсивно развивались агропромышленный и транспортный комплексы, местная промышленность. Все, что есть и еще осталось в регионе, построено именно тогда, но существует уже не в виде комплексов, а отдельных переориентированных на экспорт объектов, доходы от которых уходят за рубеж и в столичные офисы компаний.

Несмотря на всю масштабность сделанного, при советском «Ангарстрое» не были осуществлены планы создания ряда производств внутрирайонной специализации, 
позволявших снизить нарастание проблем дефицита в стране и регионе, а также общесоюзной специализации, способных дать максимальный эфффект для страны в целом. У Н. Н. Колосовского речь шла о создании на основе гидроэнергии Ангары мощного «металлургического и химического» центра, превосходящего по своим масштабам и производительности труда центр Урало-Кузбасса [1, с. 20]. Не случайно у него на первом месте указан был именно «металлургический» центр, поскольку именно организация на базе дешевой гидроэнергии крупнейшего металлургического производства, а не химического и лесохимического (их масштабы всегда ограничены соображениями охраны природы), способно дать максимальный накопительный эффект для страны в целом. На основе металлов, особенно железа, производится не просто массовая продукция, а массовая продукция долговременного пользования, дающая огромный накопительный эфффект.

В соответствии с теорией полной стоимости природной субстанции полезность (полная стоимость) произведенных в мире в докризисном 2008 году 2,3 млрд т металла, где 2,2 млрд т (95 \%) приходится на железо, составляет 5,8 трлн человеко-дней, что больше совокупной полезности (полной стоимости) ежегодно производимой пищи - 6,1 млрд т полезностью 4,6 трлн человеко-дней ${ }^{2}$ [3]. При этом пищевую субстанцию непосредственно использует (потребляет) каждый, а непосредственно использует (потребляет, амортизирует) металл в виде основных, транспортных средств и оборудования на производстве и в быту (в быту больше, чем на производстве) гораздо меньшее число человек. Поэтому, а также из-за характера потребления количество ежегодно производимой пищи потребляется обществом примерно за то же время, за которое произведено - за год или чуть более (в человеко-днях полезности пищи гораздо больше человек, чем дней). Между тем такое же по полезности количество металла (хотя в действительности его ежегодно поступающая из природы полезность даже превосходит полезность пищи) служит обществу намного

${ }^{2}$ В человеко-днях здесь измеряется не затраченный труд, а именно полезность - полная стоимость природной субстанции - сколько человек и на какое время она обеспечивает необходимым для существования конечным продуктом. Это во много раз выше затраченного труда (в 2008 г. - в 35 раз). Удельная полная стоимость природной субстанции - обратная величина ее потребления (амортизации) на душу всего населения развитых стран [3]. дольше. В человеко-днях полезности металла гораздо больше дней, чем человек. Отсюда и его огромная роль, особенно железа, в накоплении общественного эффекта от производства.

Именно этим, на наш взгляд, следует объяснять, почему в изначальных, не откорректированных ведомствами планах «Ангарстроя», как и во всех проектах индустриализации, на первом месте стояла металлургия в целом и черная металлургия в частности как производство наиболее массово потребляемого экономикой металла, способного дать максимальный накопительный эфффект, а не одна металлургия алюминия. Экономика потребляет железа в 56 раз больше, чем алюминия [3]. Поэтому с народно-хозяйственной точки зрения гораздо больший эффект в масштабе страны, чем производство на основе гидроэнергии Ангары дешевого алюминия, может дать производство дешевых и качественных сталей, сплавов, продукции титаномагниевой промышленности.

«Новый Ангарстрой». Для развития черной металлургии в Иркутской области со времени Ангарского бюро [1, с. 114-119] были подготовлены крупные запасы железных руд, огнеупорных глин, фрормовочных песков, магнезита, талька, доломитовых огнеупоров, известняка, марганца, руд редких металлов. Единственным фрактором сдерживания была бедность региона собственным коксующимся углем при больших запасах энергетических углей Иркутского бассейна. Масштабное же развитие черной металлургии сдерживало отсутствие крупнейших, подобных уральским и курским, месторождений. Но в 1980-х ситуация изменилась. Развитие третьей (восточной) общероссийской базы черной металлургии и титаномагниевой промышленности стало возможным по бездоменной технологии на основе уникальных ванадийсодержащих титаномагнетитовых руд региона [4; 5], газа Ковыктинского месторождения, энергетического угля Иркутского бассейна и гидроэнергии ангарских ГЭС. Эти источники энергии должны запустить маятник, о котором идет речь в названии. Месторождения же титаномагнетитовых руд, открытые, одно, Чинейское, - в зоне БАМа (Становое нагорье, восточная часть Кодаро-Удоканского прогиба), другое, Малотагульское, - в Восточном Присаянье, вблизи Тайшета (начало дороги на БАМ), создадут начальную траекторию движения маятника (рис. 1). 


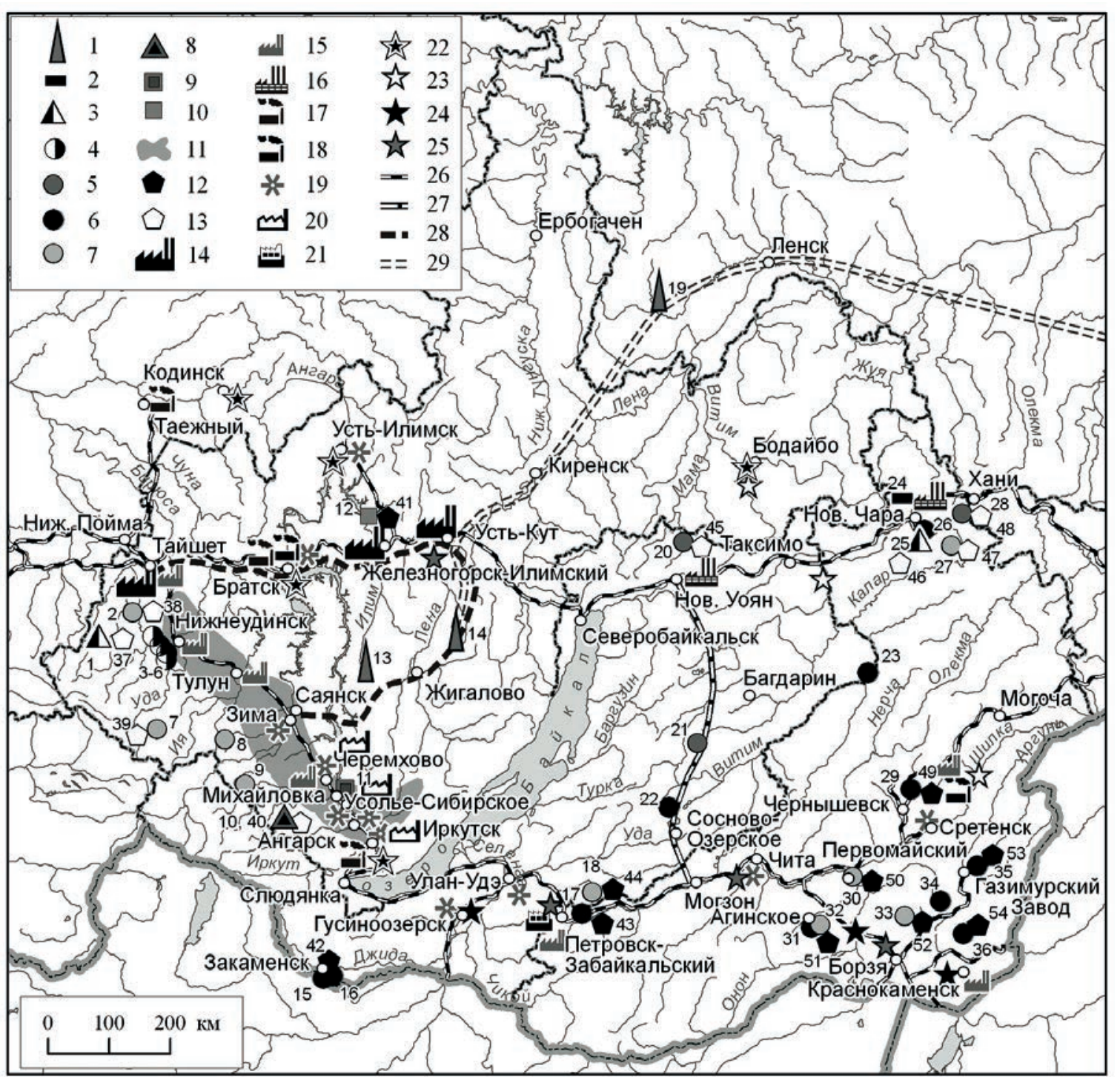

Месторождения: 1 - природный газ; 2 - каменный уголь; 3 - титаномагнетитовые руды; 4 - марганцевые руды; 5 - алюминийсодержащее сырье; 6 - цветные металлы (медь, молибден, вольфрам, свинец и цинк); 7 - редкие металлы; 8 - магнезит; 9 - глины огнеупорные; 10 - пески формовочные; 11 - Иркутский угольный бассейн и прочие месторождения нерудного сырья для черной металлургии в примерных его границах (глины огнеупорные, пески формовочные, магнезит, тальк, доломитовые огнеупоры, известняки, кварциты). Горно-обогатительные комбинаты и рудники: 12 - действующие и законсервированные; 13 - планируемые. Заводы и комбинаты: 14 - черная металлургия полного цикла (предлагаемая); 15 титаномагниевая промышленность и металлургия сплавов (предлагаемая), в том числе законсервированный Тайшетский алюминиевый завод; 16 - глиноземно-туковые комбинаты (предлагаемые); 17 - алюминиевые заводы действующие (Иркутский, Братский); 18 - заводы ферросплавов - действующий (Братский) и законсервированный (Жирекенский); 19 - заводы машиностроительные и металлообрабатывающие предлагаемые, законсервированные и действующие; 20 - производство горного, сталеплавильного оборудования и огнеупоров: Иркутский завод тяжелого машиностроения им. В. В. Куйбышева (действует); Черемховский машиностроительный завод им. К. Маркса (близок к консервации); Восточно-Сибирский огнеупорный завод, пос. Михайловка (законсервирован); 21 - черная металлургия передельная (законсервирован). Электростанции: 22 - ГЭС действующие (Иркутская, Братская, Усть-Илимская, Мамаканская, Богучанская); 23 ГЭС планируемые (Тельмамская, Мокская, Шилкинская); 24 - ГРЭС и Краснокаменская ТЭС действующие; 25 - ТЭС планируемые, в том числе на газе (Ленская, г. Усть-Кут). Железные дороги: 26 - действующие; 27 - планируемые. Газопровод: 28 - предлагаемый; 29 - планируемый. Пояснения к цифровым обозначениям на карте приведены в таблице.

Рис. 1. Объекты Байкальского региона

(Иркутская область, Республика Бурятия, Забайкальский край), относящиеся к созданию металлургического цикла производств по проекту «Новый Ангарстрой»

(составитель карты - Н. Б. Базарова) 
Пояснения к цифровым обозначениям на карте, представленной на рис. 1

\begin{tabular}{|c|c|c|c|}
\hline $\begin{array}{l}\text { Номер } \\
\text { на карте }\end{array}$ & Название & $\begin{array}{l}\text { Номер } \\
\text { на карте }\end{array}$ & Название \\
\hline \multicolumn{4}{|c|}{ Месторождения } \\
\hline 1 & Малотагульское (Fe, Ti, V) & 19 & Чаяндинское (нефртегазоконденсатное) \\
\hline 2 & Вишняковское (Тa, $\mathrm{Nb})$ & 20 & Сыннырское (Al, сынныриты) \\
\hline 3 & Шунгулежское (Mn) & 21 & $\begin{array}{l}\text { Мухальское (Al, нефелиновые руды, пер- } \\
\text { спективное сырье для Ачинского глинозем- } \\
\text { ного комбината, Красноярский край) }\end{array}$ \\
\hline 4 & Каменское (Mn) & 22 & Озерное (Pb, Zn) \\
\hline 5 & Красное (Mn) & 23 & Орекитканское (Мо) \\
\hline 6 & Николаевское (Mn) & 24 & Апсатское (уголь каменный) \\
\hline 7 & Зашихинское $(\mathrm{Ta}, \mathrm{Nb})$ & 25 & Чинейское (Fe, Ti, V, Cu, Co, Pt, Pd, Au, Ag, S) \\
\hline 8 & Белозиминское (Тa, Nb) & 26 & Удоканское $(\mathrm{Cu}, \mathrm{Ag}, \mathrm{Au}, \mathrm{S})$ \\
\hline 9 & Гольцовое $(\mathrm{Ta}, \mathrm{Nb})$ & 27 & $\begin{array}{l}\text { Катугинское (Тa, Nb, Zr, редкие земли, } \\
\text { криолит) }\end{array}$ \\
\hline 10 & Савинское магнезитовое (MgO) & 28 & Сакунское (Al, сынныриты) \\
\hline 11 & Трошковское (глины огнеупорные) & 29 & Жирекенское (Мо) \\
\hline 12 & Игирминское (пески фрормовочные) & 30 & Завитинское (Li, Nb, Ta) \\
\hline 13 & Ангаро-Ленское (газ, конденсат) & 31 & Спокойнинское (W) \\
\hline 14 & Ковыктинское (газ, конденсат, Не) & 32 & Орловское (Тa, $\mathrm{Nb})$ \\
\hline 15 & Инкурское (W) & 33 & Этыкинское (Тa, Li, Nb) \\
\hline 16 & Мало-Ойногорское (Мо) & 34 & Бугдаинское (Mo, Pb, Zn, W, Au, Ag) \\
\hline 17 & Бом-Горхонское (W) & 35 & Ново-Широкинское $(\mathrm{Pb}, \mathrm{Zn}, \mathrm{Au}, \mathrm{Ag})$ \\
\hline 18 & Ермаковское (Be, CaF2) & 36 & Нойон-Тологойское (Pb, Zn, Ag) \\
\hline \multicolumn{4}{|c|}{ Горно-обогатительные комбинаты и рудники } \\
\hline 37 & Малотагульский & 46 & Чинейский \\
\hline 38 & Вишняковский & 47 & Катугинский \\
\hline 39 & Зашихинский & 48 & Сакунский \\
\hline 40 & Савинский & 49 & Жирекенский (законсервирован в 2013 г.) \\
\hline 41 & Янгелевский (действует) & 50 & $\begin{array}{l}\text { Забайкальский (на базе Завитинского } \\
\text { месторождения, Li, Ta, Nb), концентраты Be, } \\
\text { флюорита, Sb }\end{array}$ \\
\hline 42 & $\begin{array}{l}\text { Барун-Нарынская обогатительная фабрика, } \\
\text { действует на базе отходов бывшего } \\
\text { Джидинского W-Мо комбината }\end{array}$ & 51 & $\begin{array}{l}\text { Новоорловский (осуществляет добычу } \\
\text { только вольфрама, тантал не добывается) }\end{array}$ \\
\hline 43 & Бом-Горхонский рудник (действует) & 52 & Этыкинский (законсервирован) \\
\hline 44 & $\begin{array}{l}\text { Ермаковский (законсервирован, предпола- } \\
\text { гается возобновление) }\end{array}$ & 53 & Ново-Широкинский рудник (действует) \\
\hline 45 & Сыннырский & 54 & Нойон-Тологойский рудник (действует) \\
\hline
\end{tabular}

Обоснование перспективного спроса на продукцию будущей восточносибирской черной металлургии базируется на предположении о неизбежном и скором экономическом росте в России темпами, сравнимыми с темпами роста в СССР и недавнем Китае. В 1988 г. производство стали в стане составило 94 млн т; в 1990 г. - 90 млн т; в 1998 г. 44 млн т; в 2008 г. - 69 млн т; в 2015 г. 69 млн т; т. е. уменьшилось на 25 млн т начиная с 1988 г. и на 21 млн т начиная с 1990 г. (на $15 \%$ в соответствии с общим уменьшением промышленного производства за этот период ${ }^{3}$ ). Поэтому восстановление масштабов,

\footnotetext{
3 Индекс промышленного производства в РФ в 2016 г., по нашим оценкам, составляет 85 \% от уровня 1990 г. По причине спадов 2009 и 2015 гг. он практически равен индексу 2008 г. - 84 \%. Минимум достигался в 1998 г. - 46 \% от уровня 1990 г. Последовавший

потребностей и темпов роста экономики хотя бы до уровня середины 1980-х гг. подразумевает увеличение производства стали в стране примерно на 25 млн т. Импорт металлопродукции, который должен быть замещен внутренним производством, до мирового кризиса в 2007 г. составлял 7 млн т. Спрос КНР на качественную металлургическую продукцию может быть оценен в 10 млн т в год и более. Итого - 42 млн т. И хотя «Новый Ангарстрой» принципиально ориентирован на будущий внутренний спрос самой российской экономики при начале еe ускоренного роста, масштабный первона-

затем видимый рост был в основном связан с более полным использованием прежних советских сырьевых мощностей при их подавляющей переориентации на экспорт [3]. 
чальный спрос на продукцию высококачественной черной металлургии и титаномагниевой промышленности из-за разрушения отечественного хозяйственного комплекса и многих его звеньев, возможно, должен будет обеспечить Китай. Не исключено даже, что на примере «Нового Ангарстроя» можно будет говорить о создании особого ТПК международного уровня.

Комбинаты в Иркутской области, а предлагается их три - Усть-Кутский, Илимский и Тайшетский (рис. 1, 2), - должны работать по бездоменной технологии прямого восстановления рудного концентрата на основе энергетического угля и природного газа, дальнейшей плавки продукта - железа прямого восстановления - в электропечах и получения на этой основе качественной стали, проката, сырья для производства титана и ванадия. В России одна из технологий прямого восстановления железа под действием конвертированного кислородом природного газа (Midrex) применяется с 1983 г. на Оскольском электрометаллургическом комбинате. Для титаномагнетитовых руд и богатой как газом, так и углем Иркутской области может быть более пригодной современная комбинированная технология ITmk3 на основе энергетического угля и природного газа. Не исключена, однако, ее доработка применительно к условиям и масштабам проекта либо усовершенствование, видоизменение или развитие. Эта технология разрабатывалась компанией Hares Engineering совместно с лабораторией Nishin, Kobe Steel Ltd начиная с 1996 г., когда был открыт феномен ITmk3. Восстановление здесь происходит за счет угля, а газ используется для разогрева. Впервые в промышленных масштабах технология ITmk3 была применена в 2010 г. в США, штат Миннесота, на заводе мощностью 500 тыс. т железа в год. Проект второго аналогичного завода выполнен компанией Hares Engineering для компании SBS Steel, Казахстан, г. Актобэ. Суть технологии состоит в том, что изготавливаемые здесь же на заводе рудно-флюсо-угольные окатыши разогреваются раскаленной газово-воздушной смесью, поступающей через газовую горелку, плавятся в промышленной кольцевой печи с вращающимся подом при температуре $1450{ }^{\circ} \mathrm{C}$ и превращаются в разделенные гранулы чугуна и шлака. Шлак окончательно отделяется от чугуна после конечного охлаждения. Весь процесс от загрузки печи до выгрузки из печи длится 8-12 мин. Испытания в лаборатории Nishin показали, что при переработке титаномагнетитовых руд практиче- ски весь титан попадает в шлак. На выходе, таким образом, получается железо прямого восстановления в форме гранулированного чугуна (передельный чугун высшего качества) и $\mathrm{TiO}_{2}$ в шлаке [6]. При переработке же ванадийсодержащих титаномагнетитовых руд по технологии ITmk3 на выходе следует ожидать природно-легированный ванадиевый чугун высшего качества, который, подвергаясь плавке в электропечах, даст высококачественную природно-легированную ванадием сталь и ванадиевый шлак, пригодный для производства $\mathrm{V}_{2} \mathrm{O}_{5}$ и фреррованадия. Применение бездоменной экологически чистой технологии ITmk3 к уникальным ванадийсодержащим рудам Байкальского региона позволит, таким образом, с гораздо большей эффрективностью и всего в два приема (прямое восстановление + электрометаллургия стали) получать то, что на доменных мощностях Урала и рудах Качканарского месторождения планируют, как изложено в работе [7], получать в четыре приема: разделение титаномагнетитового концентрата на магнетитовый и ильменитовый + доменная плавка магнетитов (с получением ванадиевого чугуна и ванадиевого шлака) + плавка ильменитового концентрата (с получением чугуна и титанового шлака) + выплавка стали. К тому же электроэнергия и топливо на Урале несопоставимо дороже, чем в регионе «Ангарстроя», поэтому «зацикленность» российской черной металлургии и титаномагниевой промышленности на уральских и кузнецких заводах ныне из движителя превратилась в тормоз развития. Она больше служит интересам хозяев этих заводов, монополизировавших выпуск металлов и обогащение на нем, чем народно-хозяйственным и оборонным интересам России. Целиком опираться на металлургические мощности Урала-Кузбасса сейчас - ровно то же, что было в 1930-х гг. опираться лишь на мощности и ресурсы европейской части, о чем писал Н. Н. Колосовский, - тупиковый, бесперспективный и опасный вариант развития, имея в виду крайне малую плотность населения и экономическую маломощность (из-за откладывания реализации крупных проектов) востока России в сравнении с соседними странами.

Вводить комбинаты предполагается в порядке продвижения к местам их расположения газа из Ковыктинского месторождения, где Усть-Кут - ближайший пункт, в том числе и по существующему проекту газопровода «Сила Сибири», а от Усть-Кута до Тайшета газопровод может идти вдоль 
нефтепровода «Восточная-Сибирь - Тихий океан» (см. рис. 1). Из освоенных и энергообеспеченных территорий Усть-Кут наиболее приближен к Чинейскому месторождению (в перспективе - к Чинейскому ГОКу), расположенному в 38 км к юго-востоку от ст. Новая Чара (см. рис. 1). Его разведанные запасы - 1,5 млрд т, прогнозные ресурсы - 28 млрд т. К Малотагульскому месторождению и ГОКу - среднее течение р. Малый Тагул в 140 км к юго-западу от Тайшета - будет наиболее приближен Тайшетский комбинат: разведанные запасы 1 млрд т, прогнозные ресурсы - 2,5 млрд т. Малотагульское месторождение в целом более приближено ко всем предлагаемым комбинатам, но более труднодоступно, чем Чинейское, и работы по нему еще не велись. Чинейское месторождение и Усть-Кут являются поэтому первыми по очереди.

Усть-Кут - планируемое место прохождения второй очереди газопровода «Сила Сибири» из Иркутской области через Якутию в Китай (см. рис. 1), но подключение Ковыктинского месторождения области к этому газопроводу, на наш взгляд, нецелесообразно. Производство только 40 млн т железа прямого восстановления требует, например, по газовой технологии, применяемой на Оскольском комбинате, примерно 16 млрд $\mathrm{M}^{3}$ газа в год; газо-угольные же технологии хотя и снижают объем газа, непосредственно используемый при восстановлении железа, но в целом тоже требуют высокой степени газификации. Можно поэтому быть уверенным, что перспективные потребности не только металлургии, но и побочных отраслей и городского населения, привлекаемого для ее развития, будут сопоставимы с цифрой 16 млрд м $^{3}$ в год, что близко к планируемым объемам поставок газа в Китай из Ковыктинского месторождения - 19 млрд м ${ }^{3}$ в год (разведанные запасы месторождения - 1,9 трлн м $^{3}$ ). Столько же планируется поставлять из Чаяндинского месторождения Якутии (запасы - 1,2 трлн м³). Срок выработки разведанных запасов Ковыктинского месторождения по планам экспорта составляет 100 лет. Если же прибавить названные потребности развития металлургии, срок сокращается до 54 лет. А еще есть потребности планируемой в Усть-Куте Ленской ТЭС, Иркутской области в целом и ее не только металлургического, но и действующих нефтеэнергохимического и лесоэнергетического циклов, а также Республики Бурятия и Забайкальского края. В 1990 г. потребность в газе одной только Иркутской области, без учета черной металлургии, оценивалась на ближайшую перспективу (10 лет) в 25 млрд м $^{3}$ в год, а на дальнюю (20 лет) - в 35 млрд м $^{3}$ в год; примерно в 20 млрд м ${ }^{3}$ в год оценивались потребности Бурятии и Забайкалья [8]. При таких объемах срок выработки разведанных запасов Ковыктинского месторождения сокращается до 21 года.

Мощность каждого из комбинатов предлагается по железу - 13 млн т в год, суммарная - 39 млн т в год. Это обеспечивает попутное получение порядка 6,9 млн т $\mathrm{TiO}_{2}$ и 0,6 млн т $\mathrm{V}_{2} \mathrm{O}_{5}$ для развития титаномагниевой промышленности Иркутской области и металлургии сплавов Байкальского региона в целом (источником магния может быть крупнейшее месторождение магнезитовых огнеупоров - Савинское, см. рис. 1). По $\mathrm{TiO}_{2}$ (он используется не только для получения титана) это составит 113 \% от современного мирового производства, по возможному получению титана - $1200 \%$, ванадия - $400 \%$. Предсказываемый в России Золотой век, возможно, таким образом, будет и веком титана и ванадия.

Итак, общая мощность трех комбинатов - более 46,5 млн т железа прямого восстановления, природно-легированной ванадием стали, проката, изделий и сырья для производства титана и ванадия в год. Суть проекта в достижении крупнейших масштабов производства, что даст эфффект для страны в целом, а не просто в выпуске той или иной продукции для Иркутской области или даже Сибири. В настоящее время крупнейшим в мире является комбинат «Фукуяма» в Японии мощностью 16 млн т стали в год, еще четыре японских комбината полного цикла имеют мощности более 10 млн т в год; на втором месте находился когда-то советский Магнитогорский комбинат - 15 млн т (ныне - около 13 млн). Что касается производства железа прямого восстановления, то на Оскольском электрометаллургическом комбинате оно осуществляется четырьмя модулями прямого восстановления железа (с получением губчатого железа) общей производительностью 2,2 млн т в год, и два модуля общей мощностью 2,5 млн т горячебрикетированного железа в год предусмотрены на снабжающем комбинат Лебединском ГОКе, в сумме - 4,7 млн т в год. Крупнейшим по производству губчатого железа является завод компании Essar Steel в Индии: шесть модулей прямого восстановления железа общей мощностью 5,3 млн т в год. Мы же предполагаем в составе каждого из трех комбинатов производство более 
чем в два раза большее. Это возможно, в частности, благодаря модульному принципу ввода мощностей. Так, первый в мире завод технологии ITmk3, по-видимому, наиболее применимой к титаномагнетитовым рудам, имеет мощность 0,5 млн т гранулированного чугуна в год и два модуля, причем площадь завода, судя по фротографии, не столь велика, чтобы нельзя было предположить увеличение числа модулей (или, вернее, малых заводов, цехов) до 20 и более (возможно и укрупнение их) [6]. Именно такие мощности каждого из трех комбинатов необходимы для достижения минимальной стоимости железа, стали, титана и ванадия и организации в стране массового производства дешевого и качественного конечного продукта во всех использующих металл отраслях — от массового домостроения (на основе природно-легированных ванадием антисейсмических железобетонных конструкций) до машиностроения. Таким образом, как изображено на рис. 2, крупнейшие объемы железа прямого восстановления, качественной стали, проката, титана, ванадия, сплавов должны предназначаться не для обработки на месте, а для поставок на заводы европейской и дальневосточной частей страны, а также на экспорт, в том числе в КНР.
Но в первую очередь продукция «Нового Ангарстроя» должна предназначаться для массовых нужд российского оборонно-промышленного и железнодорожного комплексов, где спрос обеспечивается государством. Поэтому и реализация проекта наиболее целесообразна в рамках мощной общероссийской компании с полным государственным участием. Она сможет привлекать к его осуществлению в добровольно-принудительном порядке также и средства всех присутствующих в регионе частных компаний, тем более если их акциями владеет государство, а по вступлении объектов в действие обеспечит поставки продукции по низким ценам. Особо заинтересованными в проекте, на наш взгляд, должны быть «Российские железные дороги». Не случайно именно эта компания еще 16 лет назад провела 66-километровую железнодорожную ветку к Чинейскому месторождению. Ванадий, содержащийся в рудах Чинейского и Малотагульского месторождений, - основа для производства сверхпрочных рельсов. По запасам ванадия эти месторождения не просто одни из крупных в мире, а уникальные. Причем концентрация (процентное содержание) ванадия в их рудах в 10 раз больше, чем на Качканарском месторождении (ГОКе) на Урале, титана больше в 3-6 раз, железа - в 2 раза.

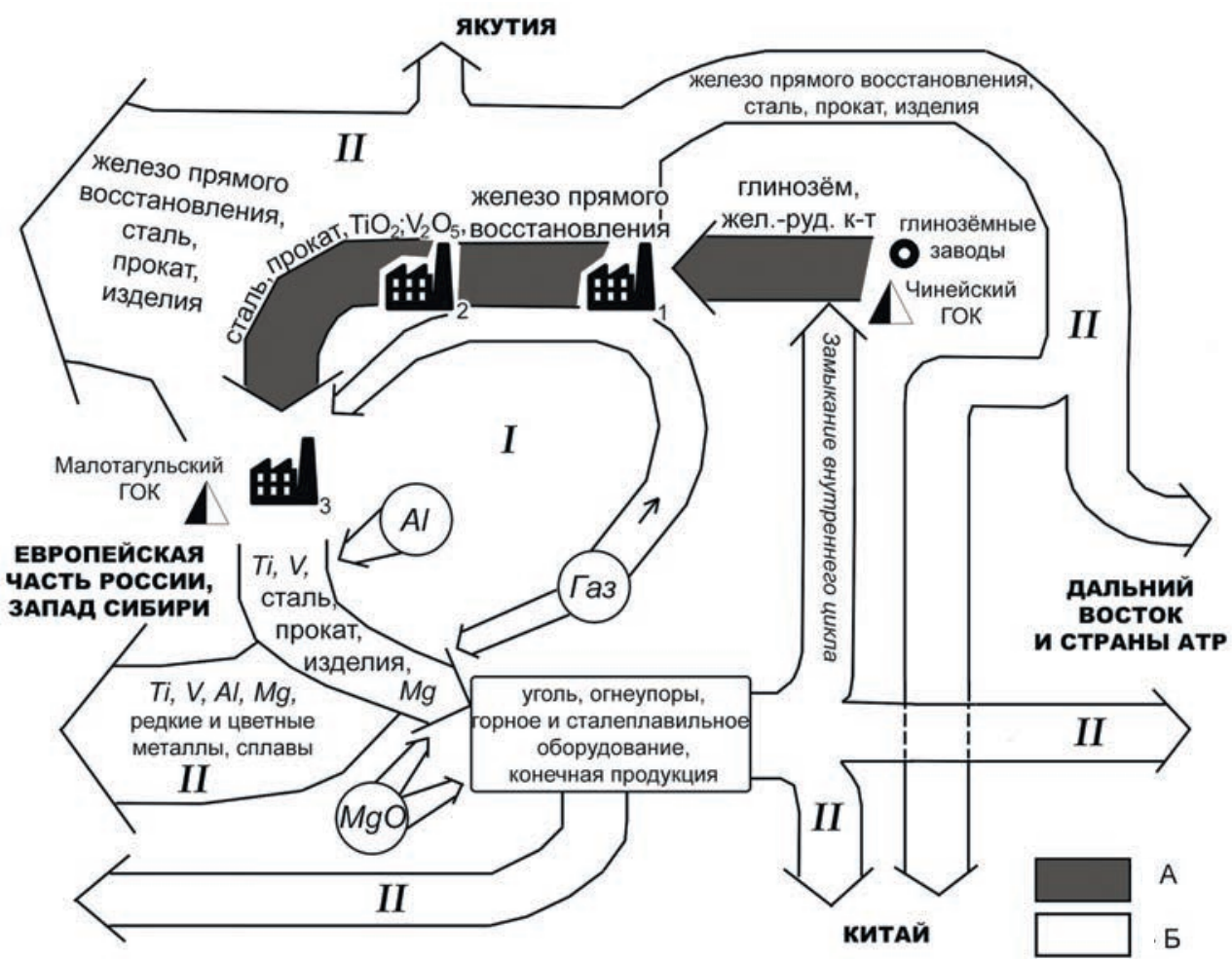

A - поток продукции, содержащий первичное сырье; Б - глубокопереработанная и конечная продукция, включая машиностроительную. Комбинаты черной металлургии полного цикла: 1 - Усть-Кутский, 2 - Илимский,

3 - Тайшетский. I - внутренний цикл; II - потоки в национальный и международный комплексы (циклы)

\section{Рис. 2. Металлургический цикл производств проекта «Новый Ангарстрой»}


Перспективное функционирование комбинатов предполагается, как отмечено, именно на основе двух месторождений. Это первоначально и создаст маятник, сходный с предложенным когда-то для Урало-Кузбасса. Расстояние от ст. Новая Чара Чинейского месторождения до Усть-Кута - 1009 км, до Железногорска-Илимского - 1160 км, от Железногорска-Илимского до ст. Тайшет Малотагульского месторождения - 517 км. От Тайшета до Иркутска по Транссибирской магистрали, по которой состав пойдет с грузом металлургической продукции, титановым и ванадиевым сырьем для многочисленных предприятий титаномагниевой промышленности и металлургии сплавов (см. рис. 1), 670 км. Итого - 2 347, что соответствует величине маятника Урало-Кузбасса (2 200 км); если же будет решено продолжить движение тех же составов в Улан-Удэ и Читу, то новый маятник в 1,5 раза превысит его (от Иркутска до Улан-Удэ - 456 км, до Читы - 1010$)$. При таких расстояниях новый маятник (весы), во-первых, как и прежний, позволит резко сократить порожний пробег железнодорожных составов и уменьшить транспортную нагрузку на БАМ и Транссиб. Во-вторых, первоначальный маятник - два месторождения и три комбината - из-за предполагаемых крупнейших масштабов производства призван снизить нагрузку на природную среду и инораструктуру мест размещения производства, уменьшить требуемые размеры карьеров и максимально увеличить и равномерно распределить по населенным пунктам число создаваемых рабочих мест.

Отметим, что реальная безработица в Иркутской области, по данным официальной статистики, стабильно держится на уровне 100-120 тыс. чел., поэтому, помимо привлечения квалифицированных специалистов металлургов извне, необходимо будет организовать обучение рабочих и инженерных кадров на месте. На Оскольком комбинате и Лебединском ГОКе занято порядка 30 тыс. чел. Производство в 10 раз большее обеспечит создание в Байкальском регионе (Иркутская область, Республика Бурятия, Забайкальский край) с учетом сопутствующих титаномагниевой промышленности, металлургии сплавов, передельной металлургии и машиностроения не менее 250-300 тыс. рабочих мест. Это позволит полностью ликвидировать в регионе безработицу.

При среднем содержании железа в необогащенной руде 34,5 \% (на Малотагульском месторождении процент может быть меньше) деятельность трех металлургиче- ских комбинатов мощностью 13 млн т железа в год потребует добычи 114 млн т руды в год (по 38 млн т на каждый комбинат). Это может быть достигнуто четырьмя карьерами мощностью по 28,5 млн т необогащенной руды в год (по два на каждом месторождении). Это предполагает мощность каждого из карьеров в 1,8 раза меньшую мощности карьера Лебединского ГОКа, обеспечивающего работу Оскольского и других комбинатов страны, но в 1,6 раза большую мощности разработанного проекта карьера первой очереди на участке Магнитный Чинейского месторождения (18 млн т необогащенной руды в год [9]). Разработка каждого из месторождений двумя карьерами соответствует существующей практике. Например, рядом с крупнейшим в Европе Лебединским карьером КМА находится крупный Стойленский карьер (ГОК).

На выходе Чинейского и Малотагульского ГОКов примем, по технологии ITmk3 и опыту Оскольского комбината, содержание железа около 70 \%, что составит для трех комбинатов потребность в 57 млн т в год. Однако, поскольку Тайшетский комбинат будет снабжаться концентратом непосредственно из ГОКа по 140-километровой ветке или другим способом (на Лебединском ГОКе предусмотрен 26-километровый продуктопровод), перевозить по магистральной железной дороге потребуется лишь 38 млн т концентрата в год (19 млн т на Усть-Кутский и 19 млн т на Илимский комбинат). Из них 28,5 млн т (по 78,10 тыс. т в сутки) пойдут с Чинейского и 9,5 млн т (по 26,03 тыс. т в сутки) сверх потребностей Тайшетского комбината - с Малотагульского ГОКа. Это потребует отправки со ст. Новая Чара четырех железнодорожных составов в сутки из, скажем, 87 восьмиосных полувагонов грузоподъемностью по 225 т (объем вагона $-137,5$ м $^{3}$, наполненность при плотности концентрата 2,8 т/M M $^{3} 58$ \%). Суммарная загруженность каждого из составов будет тогда 19,6 тыс. т4. Разгружаясь в Усть-Куте и Железногорске, они будут забирать там, и в Тайшете, сталь, чугун для передельной металлургии, металлургии сплавов, металлообрабатывающих и машиностроительных предприятий Иркутской области, Бурятии и Забайкалья (в перспективе 7 млн т и более

${ }^{4}$ В 1980-х гг. в СССР по сложному участку Транссибирской магистрали был проведен опытный состав массой 42 тыс. т. В США, Канаде и ЮАР в это же время началось регулярное обращение поездов массой 10-20 тыс. т; рекордный состав массой 71,2 тыс. т из 660 вагонов был проведен в 1989 г. в ЮАР [10]. 
в год, или 19,2 тыс. т в сутки); сырье для титаномагниевой промышленности Иркутской области ( $\mathrm{TiO}_{2}-6,9$ млн т в год, $\mathrm{V}_{2} \mathrm{O}_{5}-$ 0,6 млн т в год, всего 20,5 тыс. т в сутки); часть готового титана и ванадия на Транссибирском участке дороги для потребностей металлургии и машиностроения региона (за пределы Байкальского региона, во внешние циклы, продукция пойдет своими составами) (см. рис. 1, 2).

В обратном направлении теми же составами пойдут огнеупоры и прочее нерудное сырье (флюс) для черной металлургии 1-2 млн т в год с Восточно-Сибирского огнеупорного завода; горное и сталеплавильное оборудование с Иркутского завода тяжелого машиностроения им. В. В. Куйбышева; Малотагульский концентрат 9,5 млн т в год; уголь Иркутского бассейна для Тайшетского, Илимского и Усть-Кутского комбинатов и предлагаемых двух глиноземно-туковых комбинатов на БАМе (см. рис. 1) (этот уголь сейчас расширенно экспортируется и крупнейшая отрасль не имеет устойчивого внутреннего спроса). Отметим, что в 1930-х гг. планы Ангарского бюро предполагали, по предложению В. В. Рикмана, строительство двух комбинатов черной металлургии - Черемховского (1,2 млн т в год) и Братского (2 млн т в год) с маятниковыми перевозками углей Иркутского бассейна из района Черемхово в Братск, а Братско-Илимских руд - в Черемхово [1, c. 116]. Что касается глинозема, то его импорт в стране составляет порядка 4 млн т в год (более половины от потребности), что с лихвой покрывается освоением месторождений сынныритов и строительством двух комбинатов на БАМе $[11 ; 12]$. Таково замыкание внутреннего цикла маятника, должного передавать мощные колебания и во все внешние сореры (см. рис. 2). То, что в воспроизводственном цикле рис. 2 выглядит как круговое движение (замыкание), по железной дороге образует возвратное движение (маятник): Новая Чара - Иркутск Улан-Удэ - Чита и Чита - Улан-Удэ - Иркутск - Новая Чара (см. рис. 1).

\section{СПИСОК ИСПОЛЬЗОВАННОЙ ЛИТЕРАТУРЫ}

1. Колосовский Н. Н. Проблемы территориальной организации производительных сил Сибири / Н. Н. Колосовский. - Новосибирск : Наука, 1971. - 176 с.

2. Колосовский Н. Н. Теория экономического районирования / Н. Н. Колосовский. - М. : Мысль, 1969. $336 \mathrm{c}$

3. Никольский А. Ф. Теория устойчивого развития и вопросы глобальной и национальной безопасности / А. Ф. Никольский. - Иркутск : Сиб. кн., 2012. - 358 с.

4. Коркишко Г. С. Организация металлургического производства на базе руд Чинейского месторождения / Г. С. Коркишко, Р. В. Бабун / / Горнодобывающие комплексы Сибири и их минерально-сырьевая база. Новосибирск, 1990. - Т. 2. - С. 71-76.

5. Хренов П. М. Роль минерального сырья в развитии Восточно-Сибирской экономики / П. М. Хренов, И. Я. Кузьмин, А. Л. Александров // Горнодобывающие комплексы Сибири и их минерально-сырьевая база. - Новосибирск, 1990. - Т. 1. - С. 56-65.

6. Разаз Ю. Анализ технологий прямого восстановления оксидов металлов с применением печей с вращающимся подом / Ю. А. Разаз, И. А. Опрышко, П. И. Лобода / / Вісник Національного технічного університету України «Київський політехнічний інститут». Серія «Машинобудування». — 2011. — № 61. — С. 184-192.

7. Манзор Д. Э. Разработка технологии комплексной переработки ванадийсодержащих титаномагнетитов / Д. Э. Манзор, Б. С. Тлеугабулов // Juvenis scientia. — 2016. — № 1. - С. 13-15.

8. Перспективы развития газовой промышленности Восточно-Сибирского нефтегазового комплекса. Иркутск : СЭИСО РАН, 1990. - 425 с.

9. Секисов Г. В. Эффрективная технология освоения Чинейского месторождения ванадийсодержащих титаномагнетитовых руд / Г. В. Секисов, Е.Б. Шевкун, А. А. Якимов // Горный информационно-аналитический бюллетень. - 2002. - № 1. - С. 152-154.

10. Сотников Е. А. История и перспективы мирового и российского железнодорожного транспорта (18002100 гг.) / Е. А. Сотников. - М. : Интекст, 2005. - 112 с.

11. Архангельская В. В. Месторождения сынныритов России / В. В. Архангельская // Разведка и охрана недр. - 2014. - № 6. - С. 20-24.

12. Поляков Г. В. Проблема комплексного освоения месторождений сынныритов / Г. В. Поляков, Л. И. Панина, Т. С. Юсупов / / Горнодобывающие комплексы Сибири и их минерально-сырьевая база. - Новосибирск, 1990. - T. 1. - C. 82-87.

\section{REFERENCES}

1. Kolosovskii N. N. Problemy territorial'noi organizatsii proizvoditel'nykh sil Sibiri [lssues of the Territorial Organization of the Siberia Production Powers]. Novosibirsk , Nauka Publ., 1971. 176 p.

2. Kolosovskii N. N. Teoriya ekonomicheskogo raionirovaniya [Economic Zoning Theory]. Moscow, Mysl' Publ., 1969. $336 \mathrm{p}$. 
3. Nikol'skii A. F. Teoriya ustoichivogo razvitiya i voprosy global' noi i natsional' noi bezopasnosti [Sustainable Development Theory and Global and Homeland Security Issues]. Irkutsk, Sibirskaya kniga Publ., 2012. 358 p.

4. Korkishko G. S., Babun R. V. Organization of metallurgical production on the Basis of Chiney Deposit Ores. Gornodobyvayushchie kompleksy Sibiri i ikh mineral'no-syr' evaya baza [Siberian Mining Groups of Enterprises and their Mineral Reserve Base]. Novosibirsk, 1990, vol. 2, pp. 71-76. (In Russian).

5. Khrenov P. M., Kuz'min I. Ya., Aleksandrov A. L. The Role of Mineral Raw Materials in the Eastern Siberia Economy Development. Gornodobyvayushchie kompleksy Sibiri i ikh mineral'no-syr'evaya baza [Siberian Mining Groups of Enterprises and their Mineral Reserve Base]. Novosibirsk, 1990, vol. 1, pp. 56-65. (In Russian).

6. Razaz Yu. A., Opryshko I. A., Loboda P. I. Analysis of Metal Oxide Direct Reduction Technologies Using Rotary Hearth Furnaces. Visnik Natsional' nogo tekhnichnogo universitetu Ukraïni "Kiïvs' kii politekhnichnii institut». Seriya "Mashinobuduvannya» = Journal of the National Technical University of Ukraine "Kyiv Polytechnic Institute» . "Mechanical Engineering" Series, 2011, pp. 184-192. (In Russian).

7. Manzor D. E., Tleugabulov B. S. Razrabotka tekhnologii kompleksnoi pererabotki vanadiisoderzhashchikh titanomagnetitov [Development of technology of complex processing of vanadium titanomagnetite]. Juvenis scientia, 2016, no. 1, pp. 13-15. (In Russian).

8. Perspektivy razvitiya gazovoi promyshlennosti Vostochno-Sibirskogo neftegazovogo kompleksa [Prospects of the Development of the Gas Industry of the Eastern Siberia Oil and Gas Sector]. Irkutsk, SEI SO RAN Publ., 1990. 425 p.

9. Sekisov G. V., Shevkun E. B., Yakimov A. A. The Efficient Technology of the Development of the Chiney Deposit of Vanadium-Containing Titanium-Magnesium Ores. Gornyi informatsionno-analiticheskii byulleten' $=$ Mining information-analytical bulletin, 2002, no. 1, pp. 152-154. (In Russian).

10. Sotnikov E. A. Istoriya i perspektivy mirovogo i rossiiskogo zheleznodo-rozhnogo transporta (18002100 gg.) [History and Prospects of Railway Transportation worldwide and in Russia (1800-2100)]. Moscow, Intekst Publ., 2005. 112 p.

11. Arkhangel'skaya V. V. Russian Synnyrite Deposits. Razvedka i okhrana nedr = Exploration and Conservation of Mineral Resources, 2014, no. 6, pp. 20-24. (In Russian).

12. Polyakov G. V., Panina L. I., Yusupov T. S. An Issue of Synnyrite Full-Field Development. Gornodobyvayushchie kompleksy Sibiri i ikh mineral'no-syr' evaya baza [Siberian Mining Groups of Enterprises and their Mineral Reserve Base]. Novosibirsk, 1990, vol. 1, pp. 82-87. (In Russian).

\section{Информация об авторах}

Никольский Алексей Феликсович - доктор географических наук, ведущий научный сотрудник лаборатории георесурсоведения и политической географии, Институт географии им. В. Б. Сочавы СО РАН, 664033, г. Иркутск, ул. Улан-Баторская, 1, e-mail: nikolskij59@mail.ru.

Шуплецов Александр Федорович - доктор экономических наук, профессор, заслуженный экономист Российской Федерации, заведующий кафедрой экономики предприятий и предпринимательской деятельности, Байкальский государственный университет, 664003, г. Иркутск, ул. Ленина, 11, e-mail: ShupletsovAF@bgu.ru.

\section{Для цитирования}

Никольский А. Ф. Маятник XXI века: организация крупнейшего металлургического производства на базе руд Чинейского и Малотагульского месторождений / А. Ф. Никольский, А. Ф. Шуплецов // Известия Байкальского государственного университета. - 2018. - T. 28, № 1. - C. 44-55. - DOI: $10.17150 / 2500-2759.2018 .28(1) .44-55$.

\section{Authors}

Alexey F. Nikolsky - DSc in Geographical Sciences, Leading Researcher, Georesources and Political Geography Laboratory, V. B. Sochava Siberian Branch of the Russian Academy of Sciences, 1 Ulan-Batar St., 664033, Irkutsk, the Russian Federation; e-mail: nikolskij59@mail.ru.

Alexander F. Shupletsov - DSc in Economics, Professor, Honored Economist of the Russian Federation, Head of the Enterprise Economics and Entrepreneurship Department, Baikal State University, 11 Lenin St., 664003, Irkutsk, the Russian Federation; e-mail: ShupletsovAF@bgu.ru.

\section{For citation}

Nikolsky A. F., Shupletsov A. F. The $21^{\text {th }}$ Century Balance Wheel: Organization of the Largest Metallurgical Production Based on Ores of the Chiney and Malotagul Deposits. Izvestiya Baykal'skogo gosudarstvennogo universiteta = Bulletin of Baikal State University, 2018, vol. 28, no. 1, pp. 44-55. DOI: $10.17150 / 2500-$ 2759.2018.28(1).44-55. (In Russian). 